\title{
Assessing the Role of Pedagogy in Performance of Schools in Rural Islamabad
}

\author{
* Mohamad Sohail Khan, PhD Scholar (Corresponding Author) \\ ** Dr. Malik Inayatullah Jan, Associate Professor
}

\begin{abstract}
Rural areas in Pakistan are confronted with multiple problems including the provision of quality education to rural children. The key component of quality education is the level of pedagogy in rural schools. Effective pedagogy contributes significantly towards students' learning. The current study was conducted to assess the role of pedagogy as a major determinant in schools' performance in four rural sectors of Islamabad. The universe of this study included all public schools located in four rural sectors of Islamabad. There are a total of 275 public schools in rural Islamabad. A sample of 83 schools, both primary and secondary schools, was selected out of the total schools by using proportionate stratified random sampling technique. A self-developed questionnaire entailing the objectives of the study was used to collect data. Descriptive statistics and regression analysis were used to analyze data. Pedagogy was assessed through three major components. These are communication skills (CS), lesson planning (LP), and command of content $(C o C)$. These components were quantified accordingly. Results showed that pedagogy had a positive and highly significant effect on school performance at both primary and secondary levels. Provision of quality education is the right of rural children like those in urban settings where access to and quality of education are much better. Efforts should be made to improve and diversify pedagogical practices in rural schools and bring these at par with urban schools.
\end{abstract}

Keywords: Pedagogy, School Performance, Teacher, Education, Rural Introduction

Rural areas in most of the developing countries like Pakistan are faced with multiple problems. These mainly include poverty, sub-standard health services, weak infrastructure, unskilled labor, unemployed youth, and more importantly large-scale illiteracy. Educated rural community takes more informed decisions and also plays an active role in social, cultural and economic development of their areas (David \& Gasperini, 2003). The modern education paradigm entails governance in terms of results and outcomes rather than rules and regulations (Lindblad \& Popkewitz, 2001). The theory of pedagogical content knowledge elaborates the practical knowledge of a teacher to structure and organize subject matter for classroom teaching. It also explains conceptions and difficulties faced by students and tailor-made strategies to cater to students learning needs (Shulman, 1986).

Importance of Pedagogy in Rural Schools

Pedagogy embodies tools and techniques related to the theory and practice of teaching. It covers teaching methodology, activities, delivery, and effective communication with students aimed at achieving learning outcomes. The development of lesson plans, organizing the classroom, and delivering the relevant content are key features (Souza, 2001). Rural teachers mostly have meager facilities and short of quality learning material which in turn have an adverse effect on the learning outcomes of students. Pedagogy plays a crucial role in improving the academic environment of school. Teacher with improved pedagogical skills organizes content, lesson plan, instructional techniques and closely interacts with students in accomplishment of learning goals (Tharp \& Entz, 2003).

Pedagogy revolves around learning, content, and program standards which collectively augment the learning process (Bowman et al., 2006). Government strategies designed for improving education are mostly not based on the bottom approach and thus are not integrated. Such initiatives mostly revolve around administrative spheres with less focus on quality pedagogy and academic excellence and therefore cannot attain the desired outcomes of academic excellence quality pedagogy.

The study was conducted to ascertain the following objectives:

* Institute of Development Studies, University of Agriculture, Peshawar Email: msohailkhan75a@ yahoo.co.uk

** Institute of Development Studies, University of Agriculture, Peshawar Email: jaan.inayat@gmail.com 
1. To analyze the role of pedagogy in the performance of rural schools' in the research area.

2. To put forward recommendations for further improvement in the quality of pedagogy in rural areas

\section{Review of Literature}

Pedagogy is the theory and practice of teaching. Pedagogy enhances students' learning and has a positive effect on the academic results of the school. Pedagogy has attained prime significance in academic circles as it embodies teaching, knowledge, and skills cobbled together in immaculate sequence and coherence.

Pedagogy entails knowledge content, lesson planning, diverse techniques, and academic support material. School heads shall keep abreast of new trends and techniques in pedagogy for better monitoring and evaluation of their teachers. Academic discourse is full of research work to explore different spheres of pedagogy and further enrich the treasure of research. Coombs (1985) concluded that quality pedagogy needs to be supported by proper content so that students can comprehend easily. The content should also be in concurrence with present issues, future requirements and facilitate economic opportunities. He also highlighted that quality pedagogy ensures coherence between learning material and effective delivery taking cognizance of students' academic needs. He further elaborated education system should be designed as such that quality is embedded within the given framework. Objectives of the program, relevant syllabus, and technological support should also reflect the socioeconomic and cultural spheres of a country.

Teaching-learning manifests strong communication between teachers and students. This communication is transmitted through language which can be consequently an enabling or disabling factor in the teaching process. Engaging and collaborative teaching process enhances students' learning (Osternman, 1993).

Quality education is based on the premise of tangible outcomes in the education system. Cheng (1997) contends that quality needs to measurable associated with standards. Quality can be good or poor based on outcomes and set standards for the education program. Students are inspired by a disciplined culture in a school environment and exhibited through the actions of staff and management. The key attributes of effective teachers are commitment, devotion, capacity, and close interaction with students. These attributes can truly be reflected if there exists a cordial and supportive working milieu in a school (Craig et al., 1998).

It has been observed that teachers showing the ability to emotionally connect with the students play a major role in ensuring good quality education. The attribute of teachers connecting with students is highlighted by many research works. The quality and expertise of teachers to effectively deliver teaching content to students has a huge impact on the learning process of students and better academic results (Horsburgh, 1999). Teacher' skills, knowledge, experience, certification status, and competence are major determinants in ascertaining differential learning of students. These are more important than the effects of classroom size or other factors. Students' learning varies according to the aforementioned attributes of teachers which have a far-reaching effect on the learning process (Hammond, 1999). Hammond also posited that there is a close relationship between the qualification of a teacher and students' achievements. It was estimated that these attributes of teachers accounted for 90 percent of the total average variation in terms of students' achievements. He further elaborated that teacher is the heart of the education system so they must have polite and accommodating behavior. Teachers should effectively communicate with students and be keenly connected with them emotionally so that the learning process is strengthened and better results are achieved.

Lee and Smith (199) elaborated that teachers' communication skills are essential for academic success since they regularly and productively engage students. Frequent and productive interaction with students results in increased motivation level regarding learning and also helps in the personal growth of students as well as achievement of academic targets. Muskin (1999) concluded that efficiency is embedded in internal and external systems and policies which ensure quality education. He elaborated that the dream of quality education can only be fulfilled when required inputs and outputs are provided timely and effectively for better academic outcomes. The internal efficiency of the system includes students' rate of completion, those doing repetition, and students dropping out from schools. External efficiency of the system includes outcomes and productive engagement of students after schooling. 
Chua (2004) highlighted that clarity, lucidity, effective delivery and sequential flow of content are essential components for teachers' performance. Organized teaching with clear goals in mind is important for quality education. It was also explained that students' prior knowledge should also be ascertained to adjust teaching practice and it also necessitates the qualification of teachers to filter students.

Quality education according to Leu (2005) is ingrained in the policies and strategies of a country. Coping up with the challenge of proactive learning is an approach in which a distributed learning mechanism is adopted. This captures and combines student-centered and teacher-centered models in such a manner that the conceptual aspect of learning is not lost.

Efficacy and collective sense of responsibility on the part of teachers contribute effectively towards better classroom practices and increased learning by students even though whether teachers are placed in primary, elementary, or high schools. Teachers gradually adapt teaching attributes both conscientiously and subconsciously during their carrier and customize pedagogical practices. Marriott and Goyder (2009) posited that learning content needs to be pertinent and relevant to context as well as present and future needs should be incorporated to facilitate the application of knowledge.

The learning environment has a significant influence either positively or negatively on the learning process of a student. The learning process is considerably supported and strengthened by audio and visual aids, games, and the use of technology. Groff (2013) therefore suggested that lack of these support materials can negatively affect the teaching and learning process. The use of visual aids and technological support augments the learning process of students.

Research from a variety of disciplines evidenced that the role of pedagogy is crucial in enhancing the learning of students and ensuring better academic outcomes and goals. Pedagogy is the arena that provides a solution for desired teaching techniques and addressing the academic needs of students (Levine \& Martha, 1998). Tharp (2000) conducted extensive research on teaching practices focusing on academically weak students. The study revealed that sound teaching techniques coupled with organized application produced desired results. The most common denominator to achieve academic success is instructional activity at the classroom level.

Pedagogy is a communicative process between teacher and students where the teacher keenly observes students, reads their minds and perceptions, and adjusts his flow of ideas and words accordingly so that all students are at the same level of understanding. Students' comprehension levels can be enhanced using diverse pedagogical techniques, learning material, and practices. Teachers using innovative practices enhance the learning of students, receive feedback from students, and develop enhanced skills of inquiry. Schools thus become better learning centers and improved relationship with students is being observed.

Teachers should have good subject knowledge and develop lesson plans to transmit relevant concepts to students. Engaging sessions with students in which active participation of students is ensured in the learning process exhibits the skill set of teachers. It also reflects the commitment of teachers and the domain of effective pedagogy thus producing academic success. Students who get quality teachers perform better in academics and resultantly school performance is improved. The utilization of diverse pedagogical techniques considerably enhances students' conceptual clarity. School heads doing proper monitoring of teachers help in identifying the professional development needs of teachers. Persistent guidance and coaching of teaching staff by school heads also contribute towards the adoption of better pedagogical practices.

\section{Methodology}

The study was conducted to explore the relationship between school performance and pedagogy in rural areas of Islamabad Capital Territory (ICT). Two (III and IV) out of five zones in Islamabad are officially designated as rural zones. Zone III includes three sectors namely Bhara Kau, Nilore, and Sihala while zone VI includes the Tarnual sector. The total area of rural sectors of Islamabad is 466 square $\mathrm{km}$ (GoP, 2007). Overall there are 275 public rural schools in Islamabad. All schools situated in four rural sectors of Islamabad constituted the universe of this study. A geo-referenced map of the research area is provided in Figure 1. 


\section{Figure 1: Map of Research Area}

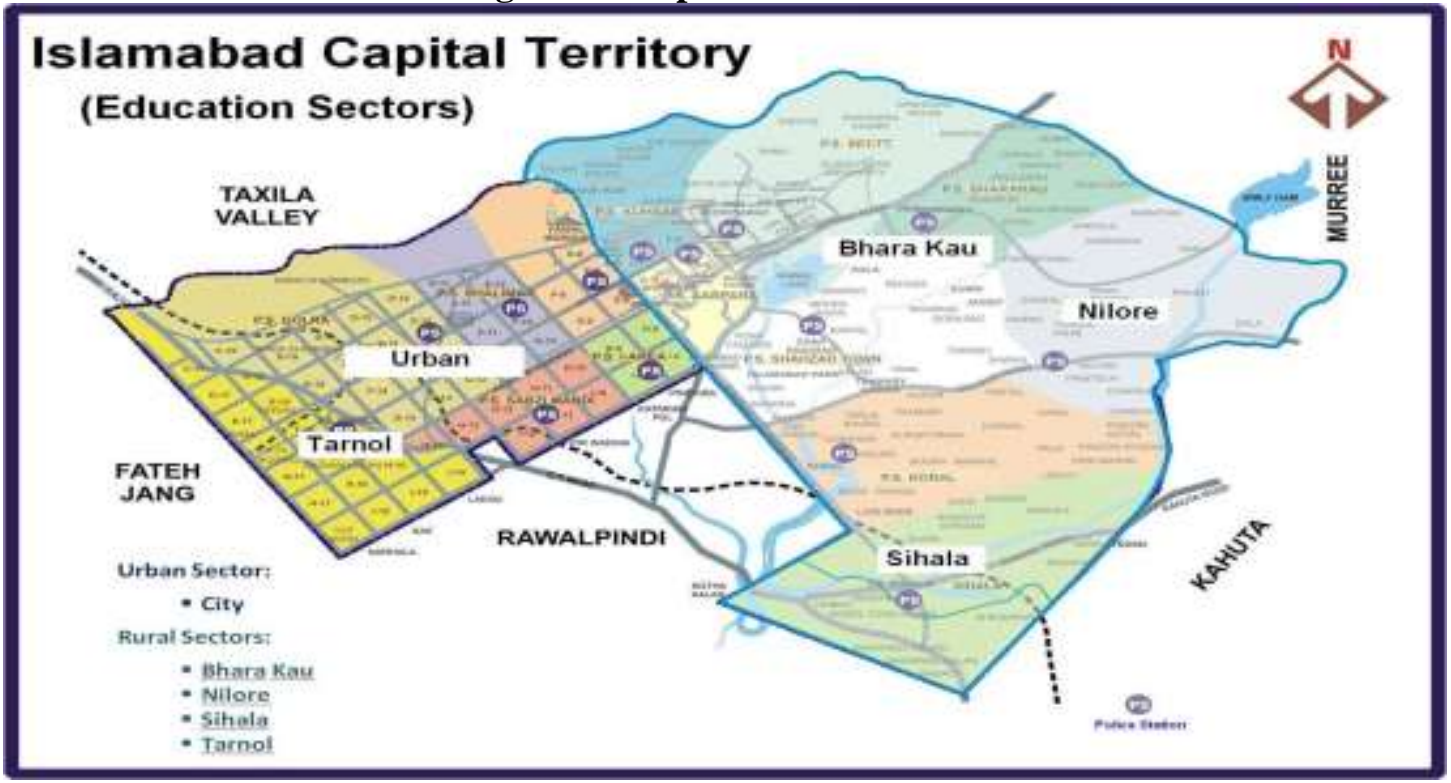

Source: Federal Directorate of Education (FDE, 2003)

The study gathered data from school heads of both primary and secondary levels in rural areas of Islamabad through questionnaire and interview schedule. Data was also collected from the community through a questionnaire regarding their perceptions and feedback. The total sample size for primary school heads was 54 and secondary schools were 29 selected from four geographically distributed rural sectors of Islamabad. To get a representative sample, 30 percent of schools were selected from the research area. The reason for selecting a 30 percent sample is that it gives us a representative sample of the total population. It captures perceptions of diverse respondents from all geographic areas of rural sectors of Islamabad. Multiple stage sampling technique was used in selecting the sample. In the first stage, the proportionate sampling technique (Cochran, 1977) was used to select 83 schools from 275 schools using the following formula:

$$
n_{i}=\frac{N_{i}}{N} n
$$

Where

$N=$ Total number of schools in the research area

$N_{i}=$ Total number of schools in each sector

$n=$ Total number of sampled schools in the research area

$\mathrm{n}_{\mathrm{i}}=$ total number of sampled schools in each sector

Table 1 Sample Selection Procedure

\begin{tabular}{lllllll}
\hline Sector & $\begin{array}{l}\text { Primary } \\
\text { schools }\end{array}$ & Subsamples & $\begin{array}{l}\text { Secondary } \\
\text { schools }\end{array}$ & $\begin{array}{l}\text { Subsampl } \\
\text { es }\end{array}$ & $\begin{array}{l}\text { Total } \\
\text { schools }\end{array}$ & Total sample size \\
\hline Nilore & 45 & 13 & 22 & 7 & 67 & 20 \\
Bhara Kau & 47 & 14 & 32 & 10 & 79 & 24 \\
Tarnual & 35 & 11 & 20 & 6 & 55 & 17 \\
Sihala & 53 & 16 & 21 & 6 & 74 & 22 \\
Total & $\mathbf{1 8 0}$ & $\mathbf{5 4}$ & $\mathbf{9 5}$ & $\mathbf{2 9}$ & $\mathbf{2 7 5}$ & $\mathbf{8 3}$ \\
\hline
\end{tabular}

The second stage entailed the division of schools into two strata based on the conduct of exams by the Federal Board of Intermediate and Secondary Education (FBISE) Islamabad, viz-a-viz., primary and secondary schools. A proportionate sample was selected from primary and secondary schools by using the aforementioned formula of proportional allocation. Thus a total of 54 primary and 29 secondary schools were selected as a sample. Details of the number of schools selected from each

\section{Analytical Approach}

The data was analyzed through descriptive analysis and also through regression analysis. To assess the role of pedagogy multiple regression analysis was used. The functional relationship between dependent and explanatory variables is shown as:

$$
\mathrm{Y}=f(P D, Q U A, E X P, G)
$$


Where $\mathrm{Y}$ is school performance, PD is pedagogy, QUA is qualification of the school head, EXP is experience of the school head and $\mathrm{G}$ is the gender of the school head.

To estimate the performance of primary and secondary schools separately, two models were used given below as:

(i) $\quad$ Regression model for primary schools:

$$
Y P_{i}=\alpha_{0}+\beta_{1} X_{1}+\beta_{2} X_{2+} \beta_{3} X_{3}+\theta_{1} D_{1}+\mu_{i}
$$

Where,

$Y P_{i}=$ Performance of the ith number of primary school measured as the students' average passing percentage during the last five years;

$\mathrm{X}_{1}=$ Pedagogy measured as quantitative indicators given on page 49

$\mathrm{X}_{2}=$ Qualification of the school head measured as level of education;

$\mathrm{X}_{3}=$ Experience measured as total years of experience as a school head (categories);

$\mathrm{D}_{1}=$ Dummy for gender of school head (= 1 if male and 0 if female);

$\alpha_{0}=$ constant of the model

$\beta i=$ regression coefficients of quantitative variables

$\theta_{i}=\quad$ regression coefficients of dummy variables

$\mu_{\mathrm{i}}=$ Error term

(ii) Regression model for secondary schools:

$Y S_{j}=\gamma_{0}+\gamma_{1} X_{1}+\gamma_{2} X_{2}+\gamma_{3} X_{3}+\theta_{1} D_{1}+\mu_{i}$

Where,

$Y S_{j}=$ Performance of the jth number of secondary school measured as students' average passing percentage during the last five years;

$\mathrm{X}_{1}=$ Pedagogy measured as quantitative indicators given on page 49

$\mathrm{X}_{2}=\quad$ Qualification of the school head measured as level of education;

$\mathrm{X}_{3}=$ Experience of the school head measured as years of experience as school head (categories);

$\mathrm{D}_{1}=\quad$ Dummy for gender of school head (= 1 if male and 0 if female);

$\gamma_{0}=$ constants of the model

$\gamma_{i}=\quad$ regression coefficients of quantitative variables

$\theta_{i}=\quad$ regression coefficients of dummy variables

Results

$\mu_{\mathrm{i}}=\quad$ Error term

Results of both primary and secondary schools are given as:

\section{Model 1: Performance of Primary Schools}

In this model, primary school performance is the dependent variable whereas education, gender, experience, pedagogy are explanatory variables. The estimated coefficients of the variables along with their respective significance levels are shown in Table 2 and discussed below. Qualification of respondents was used as a categorical variable in the model. The intermediate level qualification was used as the reference category.

Results in Table 2 show that graduate-level qualification has a positive and highly significant effect on primary school performance. It is evidenced by the coefficient of 12.46 and also highlighted by p-value $<0.000$.

Table 2: Results of Multiple Linear Regression Model for Primary School Performance

\begin{tabular}{lllll}
\hline Explanatory Variables & $\boldsymbol{B}$ & Std. Error & t-value & Sig. \\
\hline $\begin{array}{l}\text { Qualification } \\
\text { Intermediate (base category) }\end{array}$ & & & & \\
$\begin{array}{l}\text { Graduation } \\
\text { Master }\end{array}$ & 12.4652 & 3.213244 & 3.88 & 0.000 \\
MPhil and PhD & 16.02519 & 3.1892 & 5.02 & 0.000 \\
$\begin{array}{l}\text { Experience } \\
\text { Above 10 years=1, }\end{array}$ & 15.12464 & 4.2308 & 3.57 & 0.001 \\
below 10 years =0 & & & & \\
$\begin{array}{l}\text { Gender } \\
\text { (male=1,female =0) }\end{array}$ & 2.097648 & 1.782913 & 1.18 & 0.246 \\
$\begin{array}{l}\text { Percentage of pedagogy } \\
\text { Constant }\end{array}$ & & & & \\
$\mathrm{R}^{2}=0.89$ & 0.3124243 & 1.366897 & 0.23 & 0.820 \\
& 0.2875962 & 0.09331 & 3.08 & 0.000 \\
& 48.763 & 5.35359 & 9.15 & 0.000
\end{tabular}


$\mathrm{F}=36.76$

$\mathrm{P}$-value $=0.000$

Similarly master level of education of respondents had also a positive and highly significant effect on school heads as the coefficient value is 16.02 while the p-value is 0.000 . The results for $\mathrm{Ph} . \mathrm{D}$. level qualification also showed a positive and significant effect on school performance as shown by the coefficient value that is 15.12 and p-value of 0.001 . The coefficients for all three levels of education are positive implying that the qualification of a school head significantly affects school performance. The results are consistent with those of Nsubuga (2009) who reported that if principals have more qualifications and skills and these are also being displayed in management then school performance would increase significantly. Results are also similar to those of Khan (2011) who reported that school heads having higher qualifications have a positive impact on school performance.

The experience of the school head was another potential explanatory variable used in the model. There were two categories of experience of school heads, i.e., above 10 years and below 10 years. Experience below 10 years was used as the reference category. The experience of school heads is positively related to school performance as shown by coefficient 2.097 . This implies that with an increase in experience it is more likely that school performance will increase as well. Research studies regarding experience reveal mixed results regarding experience and school performance. Some studies like those of Damon et al., (2009) and Gregory et al., (2013) document that the experience of school heads has a significant effect on school performance. Other studies such as that of Nakpodia (2009) reported that the role of the school head's experience in school performance is insignificant. The study added that experience does not necessarily improve school performance.

Gender effect on school performance is an important variable that could potentially influence school performance. Gender as female was used as a reference category in the model. The results show that the gender of the school head has an insignificant effect on school performance. The results are in contrast with those of Hallinger et al., (2016) who reported that schools managed by female heads exhibit statistically meaningful results as compared with male heads. The study found that active instructional leadership displayed by female heads significantly improves school performance.

Pedagogy was used as another important explanatory variable affecting school performance and academic results. The table shows that the coefficient of pedagogy was 0.28 . It implies that a one percent increase in pedagogy raised school performance by 0.28 times. The coefficient of pedagogy is positive which shows that there had been a positive and highly significant relationship as the p-value was less than 0.001. The results are similar to those of Lee and Smith (1999), which highlight the fact that effective pedagogy is a key to better academic results. Similarly, Chetty and Friedman (2014) and Blazer (2016) also found and concluded that the role of effective pedagogy on students' performance is positive and significant.

\section{Results of Model II}

Table 3 shows the coefficients of the explanatory variables of the multiple regression model for secondary school performance. The qualification level of a school head positively influences school performance in schools and it was used as a categorical variable in the model. Graduation level qualification was used as the reference category. It was observed for secondary schools that the coefficient of Master level qualification is 4.29. The coefficient is positive thus implying that placement of a school head having Master level qualification will more likely improve secondary school performance. The result also shows coefficients for MPhil and $\mathrm{PhD}$ level education which is 3.66 implying thereby positive relationship between a higher level of education and school performance. The results, however, show an insignificant effect of qualification on school performance as the p-value is more than 0.05. The results are similar to the findings of Damon et al., (2009) in which they concluded that there is little evidence of a significant relationship between school performance and school heads' qualification. However, the results are opposite to the findings of Miska et al., (2017) and Katozai (2005) who argued that knowledge is the key requisite for school head and heads must be qualified in terms of pedagogical practices, organization, theories of education, and new dimensions to produce good results.

The experience of the school head was an important potential variable for secondary schools' performance. The coefficient of more than 10 years' experience is positive showing a value of 1.792 which implies that an experienced head is more likely to improve school performance. The significance level is more than 0.05 , which means that school heads having more than 10 years' of experience had an insignificant effect on school performance. These findings are similar to Nakpodia 
(2009) who concluded that the experience of school heads does not significantly affect school performance and not necessarily produces better academic results. The results are opposite to that of Damon et al., (2009) and Gregory et al. (2013) who concluded that principals with more experience produce better academic results.

Table 3: Results of Multiple Linear Regression Model for Secondary School Performance

\begin{tabular}{|c|c|c|c|c|}
\hline Explanatory Variables & $B$ & Std. Error & t-value & Sig. \\
\hline \multicolumn{5}{|l|}{ Graduation (base category) } \\
\hline Qualification & & & & \\
\hline Master & 4.29913 & 2.73073 & 0.86 & 0.131 \\
\hline $\begin{array}{l}\text { MPhil and PhD } \\
\text { Experience }\end{array}$ & 3.6654 & 4.2637 & 0.95 & 0.400 \\
\hline Above 10 years $=1$, below 10 years $=0$ & 1.79278 & 1.88300 & 0.238 & 0.352 \\
\hline $\begin{array}{l}\text { Gender } \\
(\text { male }=1, \\
\text { female }=0)\end{array}$ & -3.04015 & 2.49877 & -1.22 & 0.238 \\
\hline Percentage of pedagogy & .77668 & .11811 & 6.58 & 0.000 \\
\hline Constant & 32.19108 & 4.39918 & 7.32 & 0.000 \\
\hline
\end{tabular}

$\mathrm{R}^{2}=0.89$

$\mathrm{F}=20.87$

$\mathrm{P}$-value $=0.000$

The role of gender in influencing school performance was also an important variable that was analyzed. The coefficient for the effect of gender was -3.8. The coefficient of gender is negative, which implies that an increase of each male head in a school decreased school performance by 3.8 times as compared with female heads. The P-value was however insignificant for secondary school performance. The results are similar to conclusions by Hallinger et al., (2016) and Haem (2018) that female heads are more effective than male heads in schools.

Pedagogy is the key determinant in shaping school performance and academic achievement. It was an important explanatory variable used in the model. The coefficient of medium pedagogy was 0.776. It implies that a one percent increase in pedagogy increased school performance by 0.776 times. The coefficient of pedagogy is positive which shows that there had been a positive relationship between pedagogy and school performance. The significance level was 0.000 , which means that pedagogy had a highly significant effect on school performance. The findings reaffirm conclusions drawn by Osternman (1993) and Jerry (2013) that teachers who communicate with students through a harmonious and interactive manner facilitate students learning and academic achievements. The results are similar to a study conducted by Lee and Smith (1999) wherein it was concluded that effective pedagogy is instrumental in students' learning and school performance.

Pedagogy was an important variable assessed in the research study. Pedagogy plays a major role in better school performance and this notion was evidenced in the research study. The results evidenced that better pedagogy played a major role in improved school performance in both primary and secondary rural schools of Islamabad.

Pedagogy's effect on school performance was positive, substantial, and effective as the significance level was less than 0.05 for both primary and secondary schools. Schools having a high percentage of pedagogy showed better results than that of those schools which exhibited poor pedagogical percentage. It also reinforced the proven results in erstwhile research works highlighting the fact that pedagogy is an important determinant in school performance. This also further complements research conclusions during previous studies that pedagogy significantly contributed to school improvement and better results.

\section{Conclusion}

Results showed that most of the heads in both primary and secondary schools had Master level qualification. It has been concluded that qualification had a significant effect on primary school performance while an insignificant effect on secondary school performance. Results also highlighted that experience although had a positive but statistically insignificant effect on both primary and secondary schools' performance. It is also concluded based on results that male gender had positive but insignificant effect at primary level but it had negative and insignificant effect at secondary level as compared with those of female heads. Results further strengthened the conclusions drawn by some of the research works that female heads produce better results as compared with male heads both at primary and secondary level. 
The role of pedagogy is quintessential in determining academic outcomes and overall school performance. It was revealed that schools having better pedagogy played a major role in determining school performance in many of the primary and secondary schools in rural areas of Islamabad. The current study also found that pedagogy had a highly significant effect on school performance at both primary and secondary levels in rural schools of Islamabad. The underlying reason is that pedagogy is the direct relationship and communication between students and teachers. Better pedagogical practices improve the academic outcomes of students and also uplift school performance. Most of the research works concluded that pedagogy had a highly significant effect on school performance at all levels.

The role of the experience of the school head and its impact on school performance was also analyzed. It was found that experience role in school performance was positive at both primary and secondary levels but had statistically insignificant on school performance. Research works by different authors highlighted that role of experience in school performance is significant while some researchers argued that there is no significant difference between experienced school heads and less experienced school heads as regards school performance.

\section{Recommendations}

It is recommended that the bottom-up approach in rural education governance should be adopted to get real impressions from schools and community level and devise customized strategies for better educational facilities in rural areas. Efforts should be made to improve and diversify pedagogical practices in rural schools and bring these at par with better pedagogy in urban schools. Students of rural schools should also get the same quality of teaching as provided in urban areas. Government should provide more teachers in rural areas to address the shortage of teachers. Qualified and surplus teachers in urban areas should be transferred to rural schools to fulfill shortcomings and improve the academic environment. Pedagogical practices trainings from reputed master trainers in the system as well as external reputed organizations. School heads should ensure the quality of teaching through close observation, monitoring, and getting feedback from students.

\section{References}

Bowman, B., A. Ray \& J, Robbins. 2006. Report on preparing early childhood teachers to successfully educate children. Foundation for child development project on race, class, and culture in early childhood. Erikson Institute. Chicago, US.

Blazar, D. 2016. Teacher and Teaching Effects on Students' Academic Performance, Attitudes, and Behaviors. Doctoral dissertation, Harvard Graduate School of Education. Available at: Citable link http://nrs.harvard.edu/urn-3:HUL.InstRepos:27112692.

Chua, C. 2004. Perception of quality in higher education. In Proceedings of the Australian Universities Quality Forum. AUQA occasional publication. School of Business Management, Ryerson Univ. Toronto, Canada.

Cheng, C. 1997. Paper on a new direction for educational reforms in the 21st century: Hong Kong and International Contexts. Centre for Res. Dev. Hong Kong Inst. Educ. Hong Kong.

Cochran, W. 1977. Sampling Techniques. $3^{\text {rd }}$ edition, Wiley and sons. New York. US.

Craig, H., R. Kraft \& J. Plessis. 1998. A report on teacher development and making an impact. Advancing basic education and literacy project (ABEL). Human Development Network, the World Bank. Washington, DC, US.

Chetty, R. J. Friedman \& E. Rockoff. 2014. Measuring the Impacts of Teachers II: Teacher ValueAdded and Student Outcomes in Adult. American Economic Review 104(9): 2633-2679.

Coombs, P. 1985. The world crises in education: The view from the eighties. Oxford University Press. New York, US.

David, A \& L, Gasperini. 2003. Education for rural development: towards new policy responses, International Institute for Education Planning. Sustainable Development Department FAO.

Damon C., P. Martorell, and J. Rockoff. 2009. School Principals and School Performance, National Center for Analysis of Longitudinal Data in Education Research (CALDER) working paper no.38. Washington, USA.

Groff, J. 2013. Technology- rich innovative learning environments. Innovative learning environment: $1-30$.

Gregory, F., B. Eric \& G. Steven.2013. School Leaders Matter, Research paper. 3 (1). 
Hallinger, P., D. Li \& W. Wang. 2016. Gender Differences in Instructional Leadership: A MetaAnalytic Review of Studies Using the Principal Instructional Management Rating Scale. Edu. Administration Quarterly. 52 (4): 567-601.

Hammond, D. 1999. Teacher quality and student achievement: a review of state policy evidence. Seattle, WA: Center for the Study of Teaching and Policy.

Horsburgh, M. 1999. Quality monitoring in higher education: The impact on student learning: 5(1): 925.

Khan, K. 2011. A study of self-perception of the leadership role of the secondary school heads towards the improvement of standards of education model school Lahore.

Lee, V. \& J. Smith. 1999. Social support and achievement for young adolescents in Chicago: The role of school academic press: American Edu. Res. J: 21-24.

Levine, D \& R. Martha. 1998. Developmental variations and learning disorders. Cambridge, MA: Educators Publishing Service, Inc.

Leu, E. 2005. The role of teachers, schools, and communities in quality education: a review of the literature. Global Education Center. Washington, DC, US.

Lindblad, S. \& T. Popkewitz. 2001. Report on education governance and social integration and exclusion: Studies in the powers of reason and the reasons of power, Uppsala reports on education. EU.

Lodge, C (2008). Engaging student voice to improve pedagogy and learning: An exploration of examples of innovative pedagogical approaches for school improvement. International Journal of Pedagogies and Learning. Institute of Education, University of London. 4 (5) 4-19.

Marriott, N. \& H. Goyder. 2009. Manual for monitoring and evaluating educational partnerships. UNESCO: International Institute for Education Planning.

Muskin, J. 1999. Including local priorities to assess school quality: The case of save the children community schools in Mali. Comp. Educ. Review. 43 (1): 36-63.

Nakpodia. E. 2009. The influence of principals' leadership styles on teachers and students in Nigerian secondary schools, academic leadership: Online J. 7(4): 34.

Nsubuga, Y. 2009. Analysis of Leadership Styles and School Performance of Secondary Schools in Uganda. Doctoral thesis. Department of Education, Nelson Mandela Metropolitan Uni. Uganda.

Osterman, F.1993. Communication skills: A key to caring, collaboration, and change. Paper presented at the annual meeting of the university council for educational administration. Houston, US. http://www.eric.ed.gov/contentdelivery/servelet.

Qaiser, S. \& I. Hussain. 2015. Effects of private tuition on the academic achievement of secondary school students in the subject of mathematics in Kohat Division, Pakistan, Kohat University of Science \& Technology Kohat, Khyber Pakhtunkhwa. 3 (3): 258-267.

Shulman, L. S. (1986). Those who understand: Knowledge growth in teaching. Edu. Res. 15: 4-14.

Susan, E. 2007. Forum on Public Policy. Why Pedagogy Matters: The Importance of Teaching In A Standards-Based Environment Instructor, Hawaii Community College.

Souza, D. 2001. How the brain learns: A classroom teacher's guide. Fourth edition, University of Michigan, US. 2: 1-8.

Tharp, Roland G., Peggy Estrada, Stephanie S. Dalton, \& Lois A. Yamauchi. 2000. Teaching Transformed: Achieving excellence, fairness, inclusion, and harmony. Boulder, CO: Westview.

Tharp, R. \& S. Entz. 2003. From high chair to high school: Research-based principles for teaching complex thinking. Young Children. 58 (5): 38-44. 